\title{
A experiência dos representantes do sistema judiciário e suas relações com os habitantes das comarcas na região Norte de Goiás (1870-1900)*
}

\section{Resumo}

Este estudo é resultado parcial de pesquisa realizada em documentos do Poder Judiciário referidos à região Norte do Brasil (1870-1900). Nosso objetivo é caracterizar e discutir a experiência dos agentes do sistema judiciário e suas relações com os habitantes da província de Goiás. Analisamos três processos de denúncia crime contra Domingos Batista de Araujo, promotor público acusado de improbidade e vítima de dois supostos espancamentos. À luz de intensiva pesquisa em jornais publicados na região, procuramos restabelecer as motivações dos envolvidos e recompor a situação funcional dos agentes citados nos autos.

Palavras-chave: Brasil, Província de Goiás, poder judiciário, processos-crime, metodologia

Referencia para citar este artículo: CÁSSIA GUIMARÃES MELO, Rita de (2017). “A experiência dos representantes do sistema judiciário e suas relações com os habitantes das comarcas na região Norte de Goiás (1870-1900)”. En Anuario de Historia Regional y de las Fronteras. 22 (2). pp. 49-69.

Rita de Cássia Guimarães Melo: Pós-doutorado pela Universidade Federal do Rio de Janeiro (UFRJ), Brasil. Doutorado pela Universidade de São Paulo (USP), Brasil. Professora pesquisadora da Universidade Federal do Tocantins, UFT; Brasil. Correo electrónico: ritaguimaraes@uft.edu.br. Código ORCID: 00000002-7067-6079.

\footnotetext{
* O artigo apresentado para publicação é resultado de pesquisa em andamento, realizada com fontes judiciais (processos crime, testamentos e inventários), documentação inédita, que se encontra sob a guarda do Fórum de Palmas (TO) e da Escola de Magistratura (ESMAT). A pesquisa foi iniciada em 2014 e desenvolve-se com o apoio da Fundação Universidade Federal do Tocantins (UFT). O objetivo da pesquisa é compreender a história da região Norte de Goiás (XIX), atual estado do Tocantins, no campo específico dos embates ocorridos entre os representantes do sistema judiciário e os habitantes da província.
} 


\title{
The Judicial System Representatives Experience and Their Relations With The Inhabitants of The Northern Districts of Goias (1870-1900)
}

\begin{abstract}
This work is the partial result of the research made from documents of the judiciary regarding Goias province (1970-1900). Our purpose is to characterize and discuss the experience of the representatives and the relations they established with the inhabitants of the judicial districts at the province of Goias. In this essay, we analyze three processes involving Domingos Batista de Araujo, a public prosecutor victim of two alleged beatings and an accusation of dishonesty. Based on an intensive research in newspapers published in that region, we sought to reestablish the motivations of the involved in the process and rebuild the functional situation of the agents quoted in the processes.
\end{abstract}

Keywords: Brazil, Goias Province, Law Power, Criminal Processes, Methodology.

\section{La experiencia de los representantes del sistema judicial y sus relaciones con los habitantes de los distritos en la región Norte de Goiás (1870-1900)}

\section{Resumen}

Este estudio es el resultado parcial de una investigación realizada a partir de documentos del poder judicial referidos a la región Norte de Brasil (1870-1900). Nuestro objetivo es caracterizar y discutir acerca de la experiencia de los agentes del sistema judicial y sus relaciones con los habitantes de la provincia de Goiás. Analizamos tres procesos de denuncia contra Domingos Batista de Araujo, fiscal acusado de improbidad y víctima de dos supuestas golpizas. A la luz de una investigación intensiva en periódicos publicados en la región, buscamos reestablecer las motivaciones de los implicados y recomponer la situación funcional de los agentes citados en los autos.

Palabras clave: Brasil, Provincia de Goiás, poder judicial, proceso criminal, metodología. 


\section{Introdução}

Este artigo faz um recorte da pesquisa ainda em andamento, alimentada pelos documentos judiciais circunscritos à região Norte da província de Goiás, entre os anos 1870 e 1900 . O que se pretende aqui é compreender as determinações da prática jurídica objetivada em processos de denúncia que envolveram os representantes da Justiça e da administração pública em geral.

A pesquisa em documentos judicias demanda do estudioso conhecimento de áreas frequentemente pouco visitadas, como a sociologia e a filosofia do direito, bem como a história contextualizada dos códigos processual e penal e da literatura a eles referida ${ }^{1}$.

De um lado, o trato com as fontes judiciais tem exigido uma formação suplementar sobre direito e jurisprudência. A pequena bibliografia histórica sobre o funcionamento da justiça fornece elementos importantes, mas o percurso para aquisição de conhecimentos nesta área tem sido realizado frequentemente de modo solitário, através de uma bibliografia de época, ou muitas vezes a partir da própria leitura do material processual. Ao mesmo tempo, estas dificuldades têm levado os pesquisadores a entrar em contato mais direto com os personagens que habitavam os tribunais (letrados, advogados, procuradores, curadores, depositários etc.) e com o modo da construção dos argumentos jurídicos na prática processual ${ }^{2}$.

Supriu-se a falta de formação complementar, aplicando à documentação uma leitura criteriosa sustentada pelo conhecimento da historiografia nacional e regional sobre o tema e o cruzamento das fontes processuais com a busca de informações complementares nos periódicos e relatórios administrativos produzidos no século $\mathrm{XIX}^{3}$. Esse caminho se justifica, uma vez que a importância do conhecimento das leis de determinado período não alcançam, ou melhor, não dão a ver a prática efetiva dos responsáveis por aplicá-las. Há, pois, uma certa inadequação entre os códigos e sua efetiva aplicação, procedimento comum na grande parte do território brasileiro do século XIX.

Estudos realizados sobre o tema nas regiões litorâneas do Brasil, onde os ocupantes dos cargos da Justiça eram bacharéis em Direito, revelam que a aplicação das leis e da jurisprudência brasileira era um "terreno eivado de incoerências e conflitos", de "desordem" e "desentendimentos" entre as "alçadas em relação à interpretação das leis"4. Nas regiões "periféricas", distantes do litoral e das cidades desenvolvidas, as

\footnotetext{
${ }^{1}$ A jurisprudência brasileira era um "terreno eivado de incoerências e conflitos", "desordem" e ocasionando "desentendimentos" entre as "alçadas em relação à interpretação das leis". Spiller Pena, Eduardo. Pajens da Casa Imperial: jurisconsultos, escravidão e a Lei de 1871 (Campinas: Unicamp, 2001), p. 36.

${ }^{2}$ Hunold Lara, Silvia. "Legislação sobre escravos africanos na América portuguesa”, em Gallego, José Andrés (coord.), Nuevas aportaciones a la Historia Jurídica de Iberoamérica (Madrid: Fundación Histórica Tavera-Digibis-Fundación Hernando de Larramendi, Colección Proyectos Históricos Tavera, 2000), p.130, (CD-Rom).

${ }^{3}$ Ibid., p.130.

${ }^{4}$ Spiller Pena, Eduardo, Op Cit., p.49.
} 
formalidades dos códigos confrontavam-se com práticas e costumes de povoações tradicionais, analfabetas, para as quais as leis escritas eram um mistério insondável ${ }^{5}$. Os juízes e "advogados" eram em grande parte leigos, pouco preocupados em conhecer as leis e aplicá-las em decisões e julgamentos. Prevalecia a rotina dos costumes, principalmente se respaldados pelos interesses do grupo de pertencimento ${ }^{6}$.

Não apenas o emaranhado e as incongruências das leis levavam os juízes e advogados a erros de interpretação, a julgamentos e sentenças descabidas aos casos. De ordinário, era a propensão a julgar e condenar em conformidade com "ilações jurídicas subjetivas"7. Por outro lado, o desconhecimento e a indiferença mesma, pelos códigos, que, produzidos na Corte pelos jurisconsultos togados, eram considerados ineficazes, inaplicáveis em localidades pobres, distantes da dinâmica social e econômica que caracterizava algumas cidades da região Sul do Brasil.

Ao estabelecer o princípio das leis escritas e válidas para todo o território nacional, o Estado não contava com um corpo de funcionários nem capazes, nem dispostos a confrontar a lei com as violências praticadas pelos proprietários de terras. Eram ávidos por amealhar as terras mais produtivas localizadas nas beiradas dos rios para criação de gado vacum e cavalar, atividade que constituía a riqueza e fonte de renda da região. $\mathrm{O}$ interesse em expandir e arrecadar impostos não coadunava com as formas de produção dos posseiros tradicionais. Aos agentes públicos, parecia mais fácil aliarse aos poderes locais, deixando negros livres, índios e pobres entregues à lei dos mais fortes.

Os procedimentos legais dos representantes da Justiça, observáveis nos processos analisados, são aleatórios e aplicados de acordo com interesses momentâneos dos administradores: conheciam muito mal os códigos escritos e muito bem as "práticas costumeiras" relativas ao lugar. A lei geral, escrita e codificada, era confrontada pelo voluntarismo dos agentes sociais e a cultura "iletrada" das populações, uma vez que as dos moradores eram comunicadas via oral, por códigos tradicionais de ações individuais ou coletivas ${ }^{8}$.

O recurso à lei geral adotado pelos agentes governamentais era um abstrato incompreensível para a maioria, quando não para os juízes encarregados de aplicar os códigos. As camadas populares viam as leis como um obscuro expediente inventado

\footnotetext{
${ }^{5}$ Essa situação de há muito foi constatada por Prado, Jr. Formação do Brasil contemporâneo (São Paulo, Brasiliense, 1942) e discutida por: Mello e Souza, Laura de. Desclassificados do ouro: a pobreza mineira no século XVIII (Rio de Janeiro: Graal, 1982), pp. 91 ss. Mais recentemente, a historiadora retomou o tema da política administrativa: Mello e Souza, Laura de. O sol e a sombra. Política e administração na América Portuguesa do século XVIII (São Paulo: Companhia das Letras, 2009). No entanto, saber nos livros é situação muito diversa se comparada à empiria dos documentos manuscritos sobre os quais estamos debruçados há mais de dois anos.

${ }^{6}$ Essa afirmativa é uma inversão do que afirma Bobbio, Norberto. O positivismo jurídico. Lições de filosofia do direito (São Paulo: Ícone, 1995).

${ }^{7}$ Spiller Pena, Eduardo, Op Cit., p. 54.

${ }^{8}$ Andrade Arruda, Jose J. História Moderna e Contemporânea (São Paulo: Ática, 1981), pp. 95 ss.
} 
por eles, a fim de constrangê-los, de enganá-los, de roubar-lhes as propriedades e garantir direitos aos seus protegidos. Enquanto a lei escrita formalizava a prática de dominação e regulamentação estatal, os populares continuavam a recorrer às experiências consagradas pela tradição oral ${ }^{9}$. Em razão disso, são relevantes os estudos analíticos sobre os conflitos gerados pelo confronto entre as leis escritas e as práticas tradicionais, que envolveram os representantes das leis e os habitantes locais. Nesse movimento, os sertanejos eram incapazes de compreender os obscuros meandros das leis e dos regimentos; ao se envolverem em ações e processos, procuravam proteção nos grupos de poder. Apesar de analfabetos em sua maioria quase absoluta, aprendiam a dinâmica da Justiça como experiência vivida fosse como indivíduo ou grupo.

A leitura dos manuscritos demandou muito, muito tempo. Um mesmo processo passava por vários escrivães e juízes ordinários, dificultando a leitura paleográfica. Na pesquisa mesma, à medida que determinada grafia era decifrada, outro escrivão era convocado a continuar a escrita dos autos, o que exigia do pesquisador o aprendizado de outra grafia. Ao escrivão cabia escrever todos os trâmites do processo, dos depoimentos, bem como a parte dos juízes, uma vez que muitos deles ou não eram formados, ou eram alfabetizados apenas nas primeiras letras.

De ordinário, os juízes eram escolhidos e nomeados entre os proprietários de terras moradores da comarca. Muitos deles exerciam o cargo como símbolo de distinção e poder e mantinham as atividades produtivas nas fazendas de gado e plantio. Num primeiro momento, essas observações estão direta e indiretamente nas assinaturas dos processos e nas informações dos relatórios dos presidentes de província e nos anais do Ministério da Justiça. Juízes, promotores, delegados eram nomeados e destituídos por ocasião das eleições. Nomeados pelos presidentes de províncias ou pelo imperador, era frequente que, nessas oportunidades, se estabelecessem tensões pela espera de ganhar ou perder o cargo ocupado até então.

A história do Segundo Império foi atravessada por disputas de poder entre conservadores e liberais que se revezavam na direção política do país. A polaridade entre os dois partidos dominantes naquele período insuflava conflitos entre os habitantes da região e gerava acirradas brigas entre grupos e famílias. Partidários de um ou de outro lado, não era incomum que tais contendas resultassem em mortes, notadamente nas províncias e comarcas distantes do centro político de poder ${ }^{10}$. Após as eleições, as desavenças entre juízes, promotores e personalidades locais continuavam nos escritos publicados nos periódicos da capital ${ }^{11}$.

\footnotetext{
${ }^{9}$ Barreiro, José Carlos. "Thompson e a historiografia brasileira: revisões críticas e projeções”, em Revista do Programa de Estudos Pós-graduados de História, vol. XII, São Paulo, Pontifícia Universidade Católica, 1995, p. 65; Wolmer, Antônio Carlos. História do direito no Brasil. 3 ed. rev. e amp. (Rio de Janeiro: Forense, 2002), p. 54.

${ }^{10}$ Mello e Souza, Laura de. O sol e a sombra..., p. 65.

${ }^{11}$ Revel, Jacques (org.). Jogos de escalas. A experiência da microanálise, trad. Dora Rocha (Rio de Janeiro: Fundação Getúlio Vargas, 1998), p. 18.
} 
Analisar processos crime significa adentrar a história mediante uma micropartícula do espectro social, cujos atores são indivíduos anônimos, chamados a prestar contas de suas ações por um tribunal de justiça. Levados por circunstâncias, são transformados em réus ou vítimas, ou testemunhas, oportunidade em que uma partícula de suas existências ficava registrada. Uma vez produzidos por pelo Poder Judiciário, os processos criminais guardam em si a representação de um poder ${ }^{12}$, de um procedimento ritualizado de poderes e do registro sintético de um conjunto de relações, cuja materialização constitui uma abstração do real, um fragmento da realidade social dependente de contextualização. A peça processual registra o movimento temporal efetivo das ações dos juízes e escrivães, dos depoimentos, das idas e vindas do oficial de justiça, considerando que todos eles poderiam ser substituídos durante o processo. $\mathrm{O}$ interior do documento encerra a narrativa encarnada dos envolvidos no crime e as circunstâncias geradoras do processo ${ }^{13}$.

A leitura dos depoimentos deixa perceber que eles são traduzidos pelo escrivão, ou seja, que eles são sintetizados e trazem apenas informações novas ainda não constantes nos depoimentos anteriores em razão da quantidade de depoentes. São depoimentos bastante repetitivos, que pouco acrescentam ao fato objeto da denúncia crime e ao deslindamento do crime em si; em contrapartida revelam as proximidades dos homens e mulheres no cotidiano do trabalho na roça, no curral, nas andanças a cavalo pelas paragens entre a vila e a moradia. Prestadores de serviço e proprietários de terras e gado viviam próximos entre si e do código que vigia no tempo do trabalho e do lazer. $O$ valor histórico desses depoimentos é inestimável, uma vez que permite o conhecimento das circunstâncias partilhadas entre os sertanejos e o papel particular de alguns na história da região.

Os depoimentos de anônimos daquele espaço rural sertanejo, entre os anos de 1870 e 1900, trazem elementos do cotidiano deles, bem como das distâncias percorridas, dos rios que atravessavam, da raça e cor dos cavalos montados, dos apetrechos de montaria. Comumente, as informações cronológicas dos dias, meses e anos são bastante imprecisas. Ricas, no entanto, são as informações que permitem delinear diferentes níveis da estrutura social da região, da dinâmica da vida política, das relações sociais e institucionais construídas naquela região periférica, sem perder de vista os vestígios dos excluídos.

Em pesquisa nos periódicos foi possível comparar e dimensionar as motivações e os antecedentes causadores das disputas; depois de instaurados os processos, revelam-se as picuinhas políticas e o denuncismo entre os homens de poder e seus dependentes. Com isso, foi possível recompor, mesmo que em fragmentos, as ações dos juízes de direito e promotores das comarcas e dos municípios, bem como o grau de envolvimento deles com os proprietários de terras e comerciantes, cujas divergências e litígios eram acompanhados e publicados pela imprensa oficial e partidária da província de Goiás.

\footnotetext{
${ }^{12}$ Bourdieu, Pierre. Razões práticas: sobre a teoria da ação, trad. Mariza Corrêa (Campinas: Papirus, 1996), pp. 113 ss; Adorno, Sergio. Os aprendizes do poder. O bacharelismo liberal na política brasileira (Rio de Janeiro: Paz e Terra, 1988), p. 78.

${ }^{13}$ Ginzburg, Carlo. O fio e os rastros. Verdadeiro, falso, fictício, trad. Rosa Freire d'Aguiar e Eduardo Brandão (São Paulo: Companhia das Letras, 2007), p. 75.
} 
Nas disputas, a vontade individual era confrontada por limites e controles interpostos pelos representantes da lei. Os agentes da burocracia do Estado relacionavam-se entre si e com os moradores das comarcas, construindo uma intrincada rede de transmissão de interesses político-econômicos, de motivações subjetivas, animada pelas práticas efetivas não raro alheias às formalizações legais.

Como os processos não constituem séries, optou-se por analisá-los em separado, levando em consideração as singularidades de cada um, recolocando-os no lócus de sua produção e sublinhando a afirmação dos interesses coletivos e individuais entre os envolvidos. Consideradas, de início, tão somente essas variáveis, entendeu-se que esse procedimento não jogaria fora a criança com a água do banho, segundo metáfora de Ginzburg no prefácio de $O$ queijo e os vermes ${ }^{14}$. Essa opção de método releva a ausência de unidade temática rígida, mas mantém o fio cronológico e espacial. $\mathrm{O}$ repetível nessa documentação são os atores representantes dos grupos econômicos e socioculturais da região: lavradores, roceiros, vaqueiros, criadores, juízes, escrivães, delegados, oficiais de justiça ${ }^{15}$.

Do conjunto dos processos judiciais ressaltam-se as simetrias das motivações, das atitudes e dos interesses dos grupos: agentes jurídicos e habitantes das localidades referidas nos autos. Segundo Ginzburg, “[...] selecionar como objeto de conhecimento apenas o que é repetível e, por isso, passível de serialização, significa pagar um preço, em termos cognoscitivos, muito alto". Se a "documentação é falha" sob o ponto de vista cronológico e temático, "âmbitos como a história das ideias e a história política... escapam por definição" da serialização, que "anula as particularidades da documentação existente em benefício do que é homogêneo e comparável"16. A raridade e exiguidade desses documentos exigem do inquisidor um procedimento "profundamente desconfiado". Mas o inquisidor é distinto do historiador, que não busca a verdade, mas indícios e detalhes capazes de lançar luz sobre a existência de segmento social, cujas práticas estão registradas em documentos oficiais.

O movimento dos agentes sertanejos caracteriza-se por uma dinâmica perene de "conflitos" e "contradições", “[...] acompanhados [no entanto] da contínua formação de novos níveis de equilíbrio, instavelmente sujeitos a novas rupturas ${ }^{17}$. Regidos por interesses semelhantes, esses grupos compartilham o espaço vital do sertão em luta renhida por terra, gado e água. Em outras palavras, Carvalho Franco refere-se à "relativa indiferenciação da estrutura social e [à] fraca discriminação das linhas de

\footnotetext{
${ }^{14}$ Ginzburg, Carlo. O queijo e os vermes. O cotidiano de um moleiro perseguido pela Inquisição, trad. Maria Betânia Amoroso (São Paulo: Companhia das Letras, 2006), p. 25.

${ }^{15}$ Levi, Giovanni. Herança imaterial: trajetória de um exorcista no Piemonte no século XVII (Rio de Janeiro: Civilização Brasileira, 2000), p. 16.

${ }^{16} \mathrm{Na}$ sequência, reitera: “[...] que o conhecimento histórico implique a construção de séries documentais, é óbvio. Menos óbvia é a atitude que o historiador deve adotar em relação às anomalias que afloram na documentação. [...] Todo documento, inclusive o mais anômalo, pode ser inserido numa série. Não só isso: pode servir, se analisado adequadamente, a lançar luz sobre uma série documental mais ampla". Ginzburg, Carlo. O fio e os rastros..., pp. 261-262.

${ }^{17}$ Ibid. p. 45.
} 
A experiência dos representantes do sistema judiciário e suas relações com os habitantes...

poder, aliadas ao domínio uniforme da cultura e à comunhão em um sistema simples de valores claramente definidos" $" 18$.

São raros os registros históricos da presença de roceiros, vaqueiros e agregados na região Norte de Goiás, o sertão do século XIX. Nas fontes documentais dos Oitocentos, a história brota ao rés do chão nos depoimentos registrados nos processos em estudo ${ }^{19}$. Esses grupos sociais, aliás, perpassam os documentos oficiais, cujos testemunhos orais subsistem escritos e deformados ${ }^{20}$. As mesmas considerações de Thompson sobre a cultura popular na Inglaterra do século XVIII -onde então encontrar os iletrados se a lei "[...] não penetra nos lares rurais, não aparecem nas preces das viúvas, não decora as paredes com ícones, nem dá forma à perspectiva de cada um"- fazem coro à situação das sociedades rurais do Brasil no século XIX ${ }^{21}$.

\section{Domingos Baptista de Araujo, um promotor sertanejo}

O promotor Domingos Baptista d'Araujo (1843-?) conservou-se no cargo por duas décadas. A vida funcional desse promotor [doravante referido como promotor Baptista] começou graças aos atos oficiais e decretos dos governos da província de Goiás, que ora o nomeavam, ora o exoneravam dos cargos que ocupou de 1877 a 1900. Os jornais da época dão conta de que foi vítima de espancamento em 1887. Há também dois processos, um acusando-o de faltar às responsabilidades do cargo (18891894), outro como vítima de um suposto segundo espancamento, em $1891^{22}$.

O promotor Baptista, casado, era filho legítimo do capitão Caetano Baptista de Araujo e de Dona Umbelina Antonia Cardozo, conforme consta no Processo de Espancamento Promotor Domingos Baptista de Araujo, 1891-1892²3. Em 1873, aos trinta anos de idade, ingressou no serviço público como tabelião em Arraias, onde nasceu. Foi designado promotor pela primeira vez em 1877, na comarca de Boa Vista, para onde se mudou ${ }^{24}$; em seguida foi transferido para Palma ${ }^{25}$.

\footnotetext{
${ }^{18}$ A autora conclui afirmando que, "[...] se uma cultura pobre e um sistema social simples efetivamente tornam necessárias relações de recíproca suplementação por parte de seus membros, também aumentam a frequência das oportunidades de conflito e radicalizam as suas soluções". Franco, Maria Sylvia. Homens livres na ordem escravocrata (São Paulo: Instituto de Estudos Brasileiros, USP), p. 29.

${ }^{19}$ Levi, Giovanni, Op Cit., p. 25.

${ }^{20}$ Ginzburg, Carlo. O fio e os rastros..., p. 280.

${ }^{21}$ Thompson, Edward P. Costumes em comum: estudos sobre a cultura popular tradicional, trad. Rosária Eichenberg, 2ª ed. (São Paulo: Companhia das Letras, 1998), p. 19.

${ }^{22}$ Neste último, Domingos acusa Henriqueta Pinheiro Guimarães de estelionato, falsificação de cartas, pedido de empréstimo e, por último, de tentativa de assassinato. Processo de Espancamento Promotor Domingos Baptista de Araujo, 1891-1892, www.esmat.gov.br\# (17 de junho de 2015).

${ }^{23}$ Ibid., p.46.

${ }^{24}$ Correio Oficial de Goyaz, 16 de setembro de 1876, (10), p. 3, www.bn.br\# (16 de junho de 2016).

${ }^{25}$ Ibid, 13 de março de 1878, (18), p. 1 (16 de junho de 2016).
} 
Em 1879, o promotor Baptista contribuiu com a Comissão de Emancipação de Porto Imperial, subsidiária da Sociedade Emancipadora, doando $30 \$ 000$ réis, quantia equivalente ao valor de um cavalo ${ }^{26}$. Desde 1871 , após nova reforma dos códigos Penal e Processual e a promulgação da Lei do Ventre Livre, os promotores de justiça foram incumbidos de cuidar da situação jurídica dos filhos de escravos nascidos livres para que fossem registrados como tal. Como representante da promotoria nas comarcas, coube também ao promotor Baptista essa nova tarefa.

No início de 1881, Joaquim de Almeida Leite Moraes chegou à província de Goiás com a missão de organizar e preparar a primeira eleição direta dos deputados representantes da província junto à Corte. A novidade causou alvoroço nas comarcas. A chegada de um presidente, designado pelo imperador, significava mudanças na direção política e consequentes destituições e nomeações para cargos administrativos. O novo presidente tomou conhecimento das representações feitas por moradores da comarca de Palma. Diziam que em vez de denunciar e mandar prender delinquentes, o promotor Baptista agia motivado por interesses particulares, razão pela qual requeriam providências do governo.

O caso referia-se ao inventário do espanhol Domingos Antonio de Vasconcelos, que, morto em Minas Gerais, deixara como herdeiros os pais, residentes na Galisa, e dois filhos, residentes em Palma. $\mathrm{O}$ interesse nesse inventário ocasionou brigas entre as partes, e os representantes da lei foram acusados de usurpação de bens. Nos jornais há longos e intrincados relatos acusando o promotor Baptista de falsificar o testamento a fim de roubar os bens destinados aos genitores e aos órfãos do espanhol.

Fatos como esses levaram Leite Moraes a exonerar o promotor Baptista ${ }^{27}$, o que, no entanto, não pôs termo às desavenças: “[...] a luta [intrigas] tem continuado como consta das frequentes representações das autoridades contra o promotor [Baptista] e seus amigos, deste contra as autoridades"28.

Em abril de 1882, Baptista foi reconduzido ao cargo de promotor, dessa vez enviado para Cavalcante ${ }^{29}$. Nesse ano, deu forma pública à carta de "liberdade plena e

\footnotetext{
${ }^{26}$ A Tribuna Livre, 15 de dezembro de 1879, p. 3, e 15 de dezembro de 1880, p. 4, www.bn.br\# (26 de maio de 2015). Ferreira de Gilka Salles, Vasconcelos. Economia e escravidão na Capitania de Goiás, (Goiânia: Cegraf/Universidade Federal de Goiás, Coleção Documentos Goianos, núm. 24, 1992), p. 237.

${ }^{27}$ Leite Moraes, Joaquim de Almeida. Relatório dirigido à Assembleia Legislativa Provincial de Goyaz em 30 de novembro de 1881, p. 77, http://brazil.crl.edu/bsd/bsd/331/index.html\# (13 de junho de 2015, Exonerado em 3 de maio de 1881, incurso no art. 129, § 5º do Código Criminal.

${ }^{28}$ Ibid., p. 92.

${ }^{29}$ A comarca de menos de mil e quinhentos habitantes, cujos habitantes pareciam "desertores de um hospital". Situada geograficamente entre muitas serras, cercada de muitos "rios virgens" e "mananciais de ouro" havia nesta comarca muitos doentes de "bócio", "amarelão", "opilados", "febres paludosas". Cavalcante "[...] fica como que dentro de um funil, cuja posição lhe imprime um tal aspecto de tristeza, que se comunica aos semblantes de seus moradores. [...]". O Publicador Goyano, 15 de março de 1886, p. 2, www.bn.br\# (17 de julho de 2015). O julgado de Cavalcante, de onde se extraiu ouro nos fins dos setecentos, "evoluiu naturalmente para o pastoreio" e os escravos das minas e arredores ali se fixaram. Ferreira de Salles, Gilka Vasconcelos, Op Cit., p. 241.
} 
irrevogável" à escrava Sabina. Registrada em cartório, esse tipo de alforria mantinha o cativo "coartado", isto é, ele só poderia "libertar-se após atender as exigências previamente estipuladas" pelo proprietário ${ }^{30}$. De forma que Sabina deveria servi-lo enquanto ele vivesse ${ }^{31}$.

Particularmente nas últimas décadas do século XIX, era prática costumeira dos proprietários de escravos mandar publicar em jornais as alforrias concedidas, justificando-as como gesto de humanidade, se bem que, na verdade, eram motivadas por falta de recursos para mantê-los. Na região Norte de Goiás, os proprietários de poucos escravos alforriavam-nos sim, no entanto continuavam dependentes de seus senhores de quem constituíam mão de obra sem remuneração. Se verdadeira a nota publicada e a vanglória pela alforria concedida à escrava, embora sob condição, Sabina tornou-se livre de fato com a Abolição, em 1888, vez que o promotor Baptista ainda vivia em 1920.

\section{Denúncias: imposturas e impostores}

Em 1887, uma nota publicada no Correio Oficial de Goyaz ${ }^{32}$ informava que o promotor Baptista havia sido barbaramente espancado na comarca de Porto Imperial. Registrado em relatório, o fato chegou ao conhecimento do presidente da província, que fez constar a intenção de enviar à comarca força policial a fim de apoiar as autoridades nos procedimentos de investigação e "diligências cabíveis" 33 , o que de fato não se efetivou. Naquele período, as forças policiais, notadamente as do interior, eram minguadas e desproporcionais à extensão do território. Os representantes da Justiça, por sua vez, não se dispunham a deixar a capital da província e a enveredar por caminhos difíceis ${ }^{34}$, a fim de solucionar conflitos que, bem ou mal, resolviam-se entre os homens e à margem das leis $^{35}$.

\footnotetext{
${ }^{30}$ Hunold Lara, Silvia. Campos da violência: escravos e senhores na Capitânia do Rio Janeiro, 1750-1808 (Rio de Janeiro: Paz e Terra, 1988), p. 63; Chalhoub, Sidney. Visões da liberdade: uma história das últimas décadas da escravidão na corte (São Paulo: Companhia das Letras, 1990), p. 35; Viotti da Costa, Emília. Da senzala à colônia (São Paulo: Brasiliense, 1989), p. 30; Eisenberg, Peter. "Ficando livre: as alforrias em Campinas no século XIX”, em Revista Estudos Econômicos, vol. II, núm., 17. São Paulo, Universidade de São Paulo, maio/agosto de 1987, pp. 175 ss.

${ }^{31}$ Correio Oficial de Goyaz, 12 de julho de 1883, p. 3, www.bn.br\# (16 de junho de 2016).

${ }^{32}$ Ibid., 6 de agosto de 1887, p. 3.

${ }^{33}$ A força pública-os destacamentos enviados da capital para o interior da província-em vez de ser "a garantidora da ordem, era a primeira a provocar desordem”. Espírito Santo, Brigadeiro Felicíssimo do. Relatório apresentado à Assembleia Provincial de Goiás em 20 de outubro de 1887, p. 45, http://brazil.crl. edu/bsd/bsd/331/index.html\#. (18 de junho de 2015).

${ }^{34}$ Ehlert Maia, João Marcelo. "Governadores de ruínas: os relatos de viagens de Couto Magalhães e Leite Moraes”, em Revista Estudos Históricos, núm. 40, Rio de Janeiro, Fundação Getúlio Vargas, julho/ dezembro de 2007, pp. 3 ss; Rodrigues, Neuma Brilhante. Nos caminhos do Império: a trajetória de Raimundo José da Cunha Mattos, (tese doutorado), Brasília: Universidade de Brasília, Instituto de Ciências Humanas, Departamento de História, 2007, p. 35.

${ }^{35}$ Brasil-RMJ Relatório do Ministério da Justiça (Rio de Janeiro: A Secretaria de Estado do Negócios do Império, 1880), p. 35.
} 
Antes mesmo do registro do espancamento, bem como de o fato chegar ao conhecimento do presidente e das denúncias nos jornais, era do conhecimento de muitos os desmandos praticados pelo promotor Baptista, acusado de "fabricar processos" ${ }^{36}$, de desaparecer com inventários e testamentos nos cartórios da região, além de insinuações de crimes de morte.

O Publicador Goyano levantou suspeitas sobre a veracidade do dito espancamento e suposições de que se tratava de invencionice do promotor Baptista com o intuito de justificar a contínua perseguição que fazia aos desafetos e inimigos declarados. Mesmo investido de autoridade, defensor e promotor da lei e da justiça, a nota endereçada ao respeitável público não o poupou de adjetivos pouco lisonjeiros:

Na noite de 18 para 19 de julho findo, foi agredido e bem espancado por três indivíduos (segundo dizem) o Sr. Domingos Baptista de Araújo, promotor público desta comarca, o que tendo consciência de onde lhe podia vir esse presente, quis desprezar circunstâncias graves, para com toda leviandade dar como autores dessa obra os abaixo-assinados, os quais não tendo tomado parte e nem ao menos tiveram conhecimento do fato se não depois de estar ele apanhado; vem do alto da imprensa protestar contra a mais desprezível calúnia, que contra os mesmos dirigiu o Sr. Baptista, já propalando nesta cidade, já escrevendo para fora. É ser muito mau e caprichoso o homem que desprezando causa plausível, quer aproveitar-se de banalidades para caluniar a dois pais de família. Portanto, pedimos ao respeitável público para suspender qualquer juízo desfavorável que tenha feito a nosso respeito, até que a verdade apareça ${ }^{37}$.

Os autores da publicação visavam esclarecer ao público e defenderem-se das acusações que o promotor Baptista espalhava pela comarca e fora dela, de boca em boca e pela imprensa, acusando-os de responsáveis pelo dito espancamento. Lembravam aos leitores que o promotor arrumava confusões e desafetos por onde passava: "Mal vai a comarca de Porto Imperial, tendo por órgão da justiça um homem leviano, caluniador e rancoroso, comprovando o que foi nas comarcas da Palma, Boa Vista, Cavalcante e Posse"38. E mais, agia por "manha", fazendo-se de "homem miserável", posando de coitado sem recursos, não cuidando ele mesmo de esclarecer as motivações dos agressores.

Em 1889, outra publicação tratando ainda da agressão contra o promotor Baptista reacende as divergências entre os contendores. Dessa vez era Donato Pereira de Abreu, contrariado com os boatos espalhados pelo promotor Baptista, que insistia em acusar seu amigo, tenente-coronel Salvador Francisco de Azevedo [doravante referido como tenente-coronel Salvador], de ser o mandante da agressão. Desafiou o infame

\footnotetext{
${ }^{36}$ Goyaz, 18 agosto de 1887, núm. 82, p. 3, www.bn.br\# (16 de março de 2017).

${ }^{37}$ O Publicador Goyano, 10 de setembro de 1887, p. 4, www.bn.br\# (17 de julho de 2015). Assinam a nota Salvador e Manoel Gomes da Silva. Órgão do Partido Liberal. Proprietários: Tocantins \& Aranha; Redator e responsável intelectual: Jose do Patrocínio Marques Tocantins; Tipografia ao Largo do Chafariz, núm. 29; Typ. Perseverança, 1885-1889, http://acervo.bndigital.bn.br/sophia/index.asp?codigo_sophia=24725\# (16 de março de 2015).

${ }^{38}$ O Publicador Goyano, 10 de setembro de 1887, p.4, www.bn.br\# (16 de março de 2015).
} 
caluniador a tirar a máscara e desmentir suas declarações. Para dar peso e força às declarações, acrescentou novos argumentos e citou os nomes dos convivas de ambas as partes, afirmando que todos eles sabiam e conheciam os "autores" do atentado contra Baptista. Em conversas com os conhecidos de ambas as partes, Donato defendera por diversas vezes o tenente-coronel Salvador, reafirmando que ele era inocente daquelas acusações premeditadas e injustas.

Tendo em dias do mês de junho de 1887 o sr. tenente Domingos Baptista de Araújo sofrido barbaramente um espancamento, queria alguns com toda a presunção que fosse o sr. tenente-coronel Salvador Francisco de Azevedo, o autor de semelhante presente, eu que sabia da injusta aplicação caluniosa, procurava sempre defender o inocente, porém o sr. tenente Domingos mostravase malsatisfeito comigo porque sempre [que] oferecia ocasião, defendia esse inocente que a culpa presunçosa fazia recair ${ }^{39}$.

A intenção de Donato era dar satisfação pública à família do tenente-coronel Salvador, garantindo e firmando por escrito a idoneidade e a sinceridade de seus atos. Aproveitando-se da ausência de Donato ${ }^{40}$, o promotor Baptista pôs em risco os laços de lealdade que o ligavam à família do caluniado, o tenente-coronel Salvador. Tais manifestações públicas visavam, enfim, realimentar e garantir o reconhecimento coletivo das obrigações e dos laços privado-familiares ${ }^{41}$.

[...] tendo quem garantisse ao sr. Tenente-coronel Salvador e a Exma. D. Mariana, que eu perante o sr. Baptista declarava ser o sr. Salvador o autor de tão cruel espancamento, aproveito o órgão da imprensa para protestar e chamar esse infame caluniador para tirar a máscara e vir-me desmentir o que acabo de expender, [...] Podia hoje declarar o autor do bárbaro teatro que se representou no dia 18 de junho do ano acima referido como não é desconhecido em Porto Imperial, por isso julgo desnecessário, e quem ignorar, pergunte o cheira-mel que ele dirá quem são os seus autores, portanto a honra do tenente-coronel Salvador está salva, e eu espero que esse infame, não me venha responder debaixo da capa do anonimato. Julgo ter dado ao sr. tenente-coronel Salvador e seus dignos parentes uma satisfação, e provado a minha inocência ${ }^{42}$.

A nota pública explicita os "estranhamentos" intergrupos, bem como reafirma as regras do convívio social pautadas pela idoneidade, veracidade, honra e palavra empenhada. Atos declarativos como esses, prescritivos de condutas de ação pública e privada, buscam legitimidade social entre pares devidamente autorizados e reconhecidos entre si. Os envolvidos direta e indiretamente no conflito são homens cujas identidades são reconhecidas e garantidas socialmente. São autoridades representantes do Estado, da

\footnotetext{
${ }^{39}$ Ibid, p. 4.

${ }^{40}$ Espírito Santo, Brigadeiro Felicíssimo do. Relatório apresentado à Assembleia Provincial de Goiás em 20 de outubro de 1887, p. 47, http://brazil.crl.edu/bsd/bsd/331/index.html\# (21 de julho de 2015). Donato Pereira de Abreu era professor vitalício da escola de Porto Imperial até 1888, quando pediu ao presidente da província sua remoção para a comarca da Conceição.

${ }^{41}$ Viana, Oliveira. Populações meridionais do Brasil, núm. 27 (Brasília: Senado Federal, 2005), p. 103.

${ }^{42}$ Goyaz, 18 de abril de 1889, p. 4, www.bn.br\# (17 de julho de 2015).
} 
família, proprietários e comerciantes, qualidades respaldadas pela situação econômica que os elevam à condição de honrados cidadãos e páter-famílias ${ }^{43}$.

Escrever e mandar publicar denúncias em jornais da capital, isto é, "para fora" das vilas onde as desavenças ocorriam, quebrava a "harmonia doméstica" mantida pelo grupo dominante. A exposição pública das diatribes intergrupos expunha as rachaduras internas, que, na cultura rural tradicional, deveriam permanecer assunto local e privado. Denunciar desmandos praticados pelos senhores da localidade punha em risco o próprio grupo de pertencimento e os adversários ocasionais. Indivíduos encrenqueiros eram colados à margem do grupo e tidos como forasteiros, a quem restava ou ir embora da vila ou colocar-se sob a ascendência do páter-famílias da localidade ${ }^{44}$.

\section{Os esquecidos da justiça: o caso Mércias}

Naquele mesmo ano de 1889, o tenente-coronel Salvador levou o promotor Baptista às barras do tribunal, denunciando-o ao juiz municipal de faltar com os "deveres a fim de ser ele [...] responsabilizado". No auto de denúncia consta que Mércias Rodrigues Lourenço denunciara a ele "[...] as violências praticadas contra ela" por vários homens, e que o promotor Baptista não dera prosseguimento à queixa a qual [queixa] se acha até esta data entregue ao soberano esquecimento da justiça"45.

As circunstâncias e os detalhes sobre as violências sofridas pela pobre mulher não foram detalhadas no processo. O promotor Baptista justificou a tardança em dar prosseguimento à queixa de Mércias por falta do flagrante delito e do auto do corpo de delito. No dizer dele, nas comarcas e termos adjacentes faltava autoridade policial para fazer a verificação circunstanciada do crime. E para comprovar a acefalia policial, solicita do delegado substituto uma declaração anexada ao processo: “[...] todos os lugares de suplentes de delegado e de subdelegado e seus suplentes [...] [têm-se] conservado vagos, e que o mesmo atestante tem pedido demissão do cargo, que com sacrifício tem exercido"46. Mas havia outro motivo, "[...] o único delegado de polícia na localidade era um dos agressores da pobre mulher[...]".

Em outro processo em que Baptista atuou como promotor, justificou a ausência do corpo de delito em razão da distância entre o foro e o local do crime, ocorrido em lugar ermo, oportunidade em que a polícia da comarca encontrava-se "acéfala" 47. O promotor da comarca da Palma relata a ocorrência de vários crimes na região

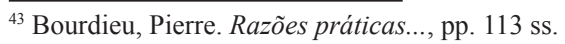

${ }^{44}$ Viana, Oliveira. Populações meridionais..., p. 103

${ }^{45}$ Processo Salvador versus Domingos Baptista de Araujo, 1889-1894, www.esmat.gov.br\# (14 de junho de 2015).

${ }^{46}$ Ibid.

${ }^{47}$ Guimarães. Melo, Rita C. "Vaqueiros e coronéis no Vale do Alto Tocantins (1889-1893): relato de um crime anunciado", em Associação Nacional dos Professores Universitários de História: conhecimento histórico e diálogo social XXVII (Natal, 2013), p. 18.
} 
A experiência dos representantes do sistema judiciário e suas relações com os habitantes...

e denuncia que “[...] o Dr. Juiz de direito da comarca [...] tem posto termo a ação da justiça, anulando todos os processos crimes - de ferimentos e mortes- que são afetos a sua decisão, desde que deles não conste o auto de corpo de delito". Uma das dificuldades era encontrar "quem se [prestasse] a exercer o cargo de oficial de justiça para fazer as intimações" 48 .

Em 1886, uma denúncia publicada no jornal denunciava o juiz da comarca de Palma, que despronunciou e mandou soltar da cadeia o mandante e o mandatário de um bárbaro assassinato. $\mathrm{O}$ autor considerou a atitude do juiz como a de quem fazia delegados e polícia “[...] não mais se [envolverem] em indagações policiais para não serem vítimas dos criminosos presos por eles e depois postos em liberdade" pelo juiz. Além disso, "[...] em um sertão vasto, onde os crimes se dão quase sempre em lugares despovoados e ermos, é difícil se não impossível conseguir um corpo de delito [...]" . Se o corpo de delito era peça fundamental para o processo de acusação, conforme constava no Código Penal e Processual, o juiz deveria avaliar as condições objetivas do lugar. Deixar de pronunciar e prender por falta do corpo de delito significava dar "amparo dos criminosos contra a ação da justiça" ${ }^{49}$.

O promotor Baptista justificou ainda ao juiz ${ }^{50}$ que a denúncia do tenente-coronel Salvador era movida pela "inimizade" que ele nutria contra si desde quando haviam disputado uma vaga ao cargo de juiz municipal. Desse conflito de interesses, o denunciante tenente-coronel Salvador começara "a empregar todos os esforços para o desprestigiar perante o juiz de direito da comarca". Disse ainda que a prova do "entranhável ódio" daquele contra si, que tinha "por hábito" escrever calúnias contra ele nos jornais, particularmente em $O$ Publicador.

Por fim, para o promotor, toda a motivação do processo de denúncia era "ódio... não causa!". O juiz não se convenceu do argumento apresentado e julgou que as ditas calúnias poderiam ter sido escritas por um "anônimo", uma vez que o promotor Baptista não apresentara provas suficientes contra o denunciante ${ }^{51}$. A denúncia foi então acatada e, em julho de 1889, o juiz mandou intimar as testemunhas oferecidas pelo denunciante, tenente-coronel Salvador.

O processo parou nessa mesma data e voltou a tramitar em 1892, quando o promotor Baptista foi nomeado curador geral dos órfãos ${ }^{52}$. Nesse ano, Joaquim Ayres da Silva foi nomeado juiz municipal interino e expediu nova convocação das testemunhas; intimou o promotor Baptista e o denunciante a comparecerem ao tribunal a fim de acompanharem os depoimentos. Das seis testemunhas arroladas na inicial do processo, duas haviam falecido. O professor Joaquim da Rocha Maya, testemunha de acusação, não compareceu para depor sob a alegação de que "na qualidade de professor público

\footnotetext{
${ }^{48}$ O Publicador Goyano, 7 de agosto de 1886, p. 2, www.bn.br\# (17 de julho de 2015).

${ }^{49}$ Ibid.

${ }^{50}$ Processo Salvador versus...

${ }^{51}$ Ibid. No processo, o promotor Domingos refere-se a dois artigos difamatórios que diz ter anexado ao processo, que, no entanto, não foram encontrados nos jornais pesquisados.

${ }^{52}$ Goyaz, 13 de fevereiro de 1891, p. 3, www.bn.br\# (17 de julho de 2015).
} 
obedecia expressa ordem do [seu] superior [...]. Barnabé Benedito Borges alegou que sofria "de febre [há] meses". Também não compareceram o promotor Baptista nem o denunciante, tenente-coronel Salvador ${ }^{53}$.

Em dezembro de 1892, o tenente-coronel Salvador mandou publicar outra denúncia, desta vez em $O$ Estado de Goyaz. Na carta enviada ao redator, afirma que o juiz interino do processo de acusação contra o promotor, Joaquim Ayres da Silva, era muito amigo do promotor Baptista, de quem era um "faz-tudo", bem como um "ignorante das leis e do direito". O promotor Baptista, por sua vez, sentindo "o vento lhe tanger a popa", procurava assegurar-se de suas alianças, fazendo-se de indispensável àquele juiz. $\mathrm{O}$ motivo de sua aliança com o juiz fora a nomeação, em 1891, do autor do processo de acusação ao cargo de promotor de justiça para exercício na comarca de Natividade. Essa nomeação, dizia ele, desagradara alguns membros do grupo, temerosos de que ele (tenente-coronel Salvador), como promotor, mesmo que em outra comarca, fizesse "reviver o que já estava esquecido"-clara referência ao assassinato do advogado Leocádio e de Miguel João Linch $^{54}-$.

O juiz municipal de então, Joaquim Ayres da Silva, era suspeito de, em 1876, ter assassinado o advogado Leocádio Manoel de Lima, na vila de Porto Imperial, sobre cuja morte o jornal oficial de Goiás publicou ofícios do presidente da província, nos quais solicitava providências e informações sobre o andamento do inquérito policial. Passados alguns meses, as solicitações rarearam a ponto de não existirem mais referências sobre o crime: caiu no esquecimento oficial, embora tenha permanecido na memória dos moradores. A última menção ao tal assassinato foi feita em uma nota, em que o delegado responsável pela investigação informava ter "colhido indícios" contra Joaquim Ayres da Silva e sua mulher, Anna Ayres da Silva, "inimigos do assassinado". O inquérito policial foi remetido ao promotor Baptista no ano de $1876^{55}$.

Além de advogado, Manoel Leocádio de Lima era examinador de provas de conclusão do ensino primário junto com Miguel João Linch -"um moço de fora"-, que, em razão de ter protegido um "negro" -que lhe pertencia, segundo Joaquim Ayres da Silva-, foi perseguido "até o ponto de fugir e ser assassinado". Em 1884, o declarante Joaquim foi chamado ao Tribunal da Relação de Goiás a fim de justificar perante o desembargador a denúncia de um "escravo" [Faustino] que o acusava de tê-lo reduzido da condição de homem livre à escravidão.

Ninguém desconhece que em nossa província, principalmente no Norte, existem mandões de aldeia, que ditam a lei ao som do bacamarte. Todo mundo sabe que Joaquim Ayres da Silva é um potentado no Porto Imperial, e que não há ali um só indivíduo que se anime a ir de encontro à sua vontade, e que, assim, um pobre diabo que lhe caia nas garras como escravo, embora possa provar a injustiça do seu constrangimento, não encontra apoio, nem em autoridades nem em particulares, contra o ditador daquele lugar ${ }^{56}$.

\footnotetext{
${ }^{53}$ Processo Salvador versus...

${ }^{54}$ O Estado de Goyaz, 15 e 18 de dezembro de 1892, p. 2, www.bn.br\# (16 de fevereiro de 2015).

${ }^{55}$ Correio Oficial de Goyaz, 7 de novembro de 1874, p. 3, www.bn.br\# (16 de maio de 2016).

${ }^{56}$ O Publicador Goyano, 9 de agosto de 1885, p. 2, www.bn.br\# (17 de julho de 2015).
} 
Em 1888, Joaquim Ayres foi eleito deputado para a Assembleia Legislativa provincial pelo Partido Liberal ${ }^{57}$. Em carta de agradecimento aos eleitores explicou que sempre reconhecera o direito à liberdade dos escravizados, embora tenha procurado provar durante quatro anos que o dito escravo Faustino lhe pertencia. Segundo o justificante, a disputa fora uma necessidade,

[...] de zelar da minha honra e reputação, que eu supunha feridas por esse processo que deu lugar a que se duvidasse de minha seriedade e do meu caráter como se fosse capaz de reduzir pessoa livre à escravidão, não me permitiu abandonar a questão aventada por Faustino, máxime quando me eram dirigidas aleivosias que muito me incomodaram ${ }^{58}$.

Sobre o tenente-coronel Salvador sabe-se que era comerciante e criador de gado. Em diversas ocasiões foi nomeado para o "encargo" de promotor em Natividade e Porto Imperial/Nacional ${ }^{59}$. O nome de Domingos consta em censo realizado pelo Ministério da Agricultura, Indústria e Comercio ${ }^{60}$ como proprietário da fazenda Gameleira, no município de Arraias, lugar onde nasceu em 1843.

\section{Conclusão}

Os cargos do Judiciário eram ocupados pelos titulados da Guarda Nacional, proprietários, comerciantes e eleitores, poucos deles letrados. Os bacharéis em Direito, nomeados pelo imperador, não permaneciam nas localidades destinadas a eles. Uma rápida leitura de $O$ Correio Oficial da província é suficiente para averiguar sobre as incessantes nomeações, remoções, pedidos de licença "para tratar da saúde" e as intermináveis prorrogações concedidas aos juízes nomeados-quase nunca negadas pelo Ministério da Justiça. Sobre essa situação, Leite Moraes escreveu ser "raríssimo" o juiz permanecer numa comarca distante à de origem: “[...] gasta-se nesta província [de Goiás], inutilmente, muito dinheiro com a administração da justiça [...]"61.

Com gastos ou não, o fato é que a justiça faltava particularmente no Norte da província de Goiás, “[...] que está sempre em constante agitação; não há um só termo que não ofereça uma lista oficial mais ou menos grave, ao passo que o Sul conserva-se inalteravelmente em sossego". Uma das causas da "intranquilidade" era imputada à

\footnotetext{
${ }^{57}$ Goyaz, 19 de outubro de 1888, p. 2, www.bn.br\# (17 de julho de 2015).

${ }^{58}$ Ibid, 21 de outubro de 1888, p. 2.

${ }^{59}$ Natividade, São Jose do Duro, Pontal, Descoberto do Carmo e Conceição formam um conjunto de povoações remanescentes do período aurífero, denominado de setentrião goiano. Acima destas povoações “[...] estava o desconhecido pouso dos gentios Xavante, Acroá e outras tribos aguerridas, região de perigo, fronteira natural entre o invasor e o nativo". Ferreira de Salles, Gilka Vasconcelos. Economia e escravidão na Capitania de Goiás (Goiânia: Cegraf/Universidade Federal de Goiás, Coleção Documentos Goianos, núm. 24, 1992), p. 241.

${ }^{60}$ Brasil-RMAIC. Relatório do ministro da Agricultura Indústria e Comércio enviado ao Presidente da República (Rio de Janeiro: Imprensa Oficial, 1926), p. 103.

${ }^{61}$ Leite Moraes, Joaquim de Almeida. Relatório dirigido à Assembleia Legislativa Provincial de Goyaz, em 30 de novembro de 1881, p. 57, http://brazil.crl.edu/bsd/bsd/331/index.html\# (31 de janeiro de 2015).
} 
situação funcional dos membros do Judiciário, cujos juízes eram interinos em todos os termos e comarcas. "Não temos, ao Norte, um só juiz municipal formado, não existe um só advogado devidamente habilitado, a promotoria em todas as comarcas está exercida por cidadãos sem a capacidade profissional [...]" ${ }^{62}$.

Leite Moraes responsabilizava os juízes municipais, ordinários e suplentes, pelas "agitações" e "conflitos intermináveis", "plantados" por eles mesmos entre os habitantes das localidades de atuação:

Esta luta desagradável [...] entre promotor, o juiz de direito interino e o juiz municipal da comarca da Palma. Este denunciava o promotor ao juiz de direito, e o promotor por sua vez denunciava o juiz municipal ao juiz de direito, e este à Relação, representando ao mesmo tempo ao governo, e acusando-se reciprocamente $[\ldots]^{63}$.

A interinidade na magistratura e nos ofícios de justiça era o "grande mal”, responsável pela anarquia da estrutura administrativa das províncias "colocadas a grande distância da capital" ${ }^{4}$. Um país dividido em "centro" e "periferia" mantinha a partição justificadora das disparidades econômicas. "O litoral servia ao progresso e à civilização, e o sertão representava a barbárie, lugar de dispersão populacional, onde a lei não penetrava" ${ }^{65}$. Para além dessas divisões, o Judiciário demorou a conquistar autonomia frente ao Legislativo e à " [...] prática recorrente do Executivo de questionar as decisões do Judiciário, chegando mesmo a forçar sua modificação punindo magistrados", inviabilizava a constituição do Judiciário enquanto poder autônomo" $" 66$.

A administração da justiça nas regiões distantes dos centros "desenvolvidos" ficou entregue aos subalternizados, que, apesar de investidos do cargo, submetiam-se aos poderes locais. Os relacionamentos pessoais constituíam laços mais fortes se comparados ao poder impessoal, imaterial do Estado. Por outro lado, ater-se às prerrogativas do cargo e fazer valer a perspectiva pública poderia significar trair o grupo e a família. Ocupar um cargo na administração não significava para os homens da localidade o esquecimento das rivalidades preexistentes entre os clãs longamente construídas e alimentados por laços de solidariedade. Não lhes eram estranhas as tensões que permeavam a comunidade em que haviam nascido.

\footnotetext{
${ }^{62}$ Ibid.

${ }^{63}$ Ibid.

${ }^{64}$ Ibid., p. 49.

${ }^{65} \mathrm{O}$ pensamento conservador não se restringia à crítica às terras remotas: “[...] o grosso da população carecia de instrução, de moral e de hábitos saudáveis de subordinação e de trabalho; por outro lado, os 'poderosos' eram movidos unicamente por interesses particulares, reforçando a desordem e o arbítrio". Nunes Ferreira, Gabriela. "Visconde do Uruguai: teoria e prática do estado brasileiro", em Botelho, André e Moritz Schwarcz, Lilian (org.), Enigma chamado Brasil (São Paulo: Companhia das Letras, 2009), pp. 21-22. Dolhnikoff, Miriam. "Elites regionais e a construção do estado nacional”, em Jancsó, István (org). Brasil: formação do estado e da nação, Coleção Estudos Históricos, núm. 50 (São Paulo: Hucitec/Unijuí/ Fapesp, 2003, p. 89.

${ }^{66}$ Sá Netto, Rodrigo. "O Império brasileiro e a Secretaria de Estado dos Negócios da Justiça (1821-1891)”, em Memória da Administração pública brasileira (Rio de Janeiro: Arquivo Nacional, Cadernos Mapas m. 2, 2011), pp. 10-11, http://www.portalan.arquivonacional.gov.br/media/2011\# (09 de julho de 2015).
} 
A experiência dos representantes do sistema judiciário e suas relações com os habitantes...

Os juízes, promotores, delegados e oficiais de justiça, a polícia conheciam os aderentes, os agregados e os afiliados que, em último caso, trabalhavam nas casas deles, nas fazendas, roças, currais, e serviços ilícitos. Eram do conhecimento de todos os valores morais reguladores daquelas relações de interdependência. Essa proximidade espacial contaminava e impedia o estabelecimento de uma justiça pautada pela neutralidade

\section{Fontes}

\section{Fontes primárias}

\section{Arquivo}

Processo de Espancamento Promotor Domingos Baptista de Araujo, 1891-1892, http//www.esmat.gov.br\#.

Processo Salvador versus Domingos Baptista de Araujo, 1889-1894, http//www. esmat.gov.br\#.

Processo Bernardino Augusto Pinheiro Canguçu versus Francisco Pereira Lobato, 1889-1893, www.esmat.gov.br./.

A Tribuna Livre, http://memoria.bn.br/DocReader/717592/278/.

BRASIL-RMJ Relatório do Ministério da Justiça. Rio de Janeiro: Secretaria de Estado do Negócios do Império, 1880. http://brazil.crl.edu/bsd/bsd/u1880/contents. html.

BRASIL-RMAIC. Relatório do ministro da Agricultura Indústria e Comércio enviado ao Presidente da República. Rio de Janeiro: Imprensa Oficial, 1926. http://brazil.crl. edu/bsd/bsd/u2022/000001.html.

Correio oficial de Goyaz, http://memoria.bn.br/DocReader/index,html.

Espírito Santo, Brigadeiro Felicíssimo do. Relatório apresentado à Assembleia Provincial de Goiás em 20 de outubro de 1887, http://brazil.crl.edu/bsd/bsd/331/ index.html\#.

Goyaz. Órgão do partido liberal, http://memoria.bn.br/DocReader/1880-1900,index.

Leite Moraes, Joaquim de Almeida. Relatório dirigido à Assembleia Legislativa Provincial de Goyaz, em 30 de novembro de 1881, http://brazil.crl.edu/bsd/bsd/331/ index.html\#.

O Estado de Goyas, http://memoria.bn.br/DocReader/246590/17.

O publicador goiano, http://memoria.bn.br/DocReader/716774/5. 


\section{Fontes Secundárias}

Livros

Adorno, Sergio. Os aprendizes do poder. O bacharelismo liberal na política brasileira. Rio de Janeiro: Paz e Terra, 1988.

Arruda, Jose J. Andrade. História Moderna e Contemporânea. São Paulo: Ática, 1981.

Bourdieu, Pierre. Razões práticas: sobre a teoria da ação, trad. Mariza Corrêa. Campinas: Papirus, 1996.

Carvalho Franco, Maria Silvia. Homens livres na ordem escravocrata. São Paulo: Instituto de Estudos Brasileiros, Universidade de São Paulo, 1969.

Chalhoub, Sidney. Visões da liberdade: uma história das últimas décadas da escravidão na corte. São Paulo: Companhia das Letras, 1990.

Ferreira de Salles, Gilka Vasconcelos. Economia e escravidão na Capitania de Goiás, Goiânia: Cegraf/Universidade Federal de Goiás, Coleção Documentos Goianos, núm. 24, 1992.

Ginzburg, Carlo. O queijo e os vermes. O cotidiano de um moleiro perseguido pela Inquisição, trad. Maria Betânia Amoroso. São Paulo: Companhia das Letras, 2006.

Ginzburg, Carlo. O fio e os rastros. Verdadeiro, falso, fictício, trad. Rosa Freire d'Aguiar e Eduardo Brandão. São Paulo: Companhia, das Letras, 2007.

Hunold Lara, Silvia. Campos da violência: escravos e senhores na Capitânia do Rio Janeiro, 1750-1808. Rio de Janeiro: Paz e Terra, 1988.

Hunold Lara, Silvia. "Legislação sobre escravos africanos na América portuguesa", em Gallego, José Andrés (coord.), Nuevas aportaciones a la Historia Jurídica de Iberoamérica. Madrid: Fundación Histórica Tavera -Digibis-Fundación Hernando de Larramendi, Colección Proyectos Históricos Tavera, 2000.

Levi, Giovanni. A herança imaterial: trajetória de um exorcista no Piemonte no século XVII. Rio de Janeiro: Civilização Brasileira, 2000.

Mello e. Souza, Laura. Desclassificados do ouro: a pobreza mineira no século XVIII. Rio de Janeiro: Graal, 1982.

Mello e. Souza, Laura. O sol e a sombra. Política e administração na América Portuguesa do século XVIII. São Paulo: Companhia das Letras, 2009.

Prado Jr., Caio. Formação do Brasil contemporâneo. São Paulo: Brasiliense, 1942. 
A experiência dos representantes do sistema judiciário e suas relações com os habitantes...

Revel, Jacques (org.). Jogos de escalas. A experiência da microanálise, trad. Dora Rocha. Rio de Janeiro: Fundação Getúlio Vargas, 1998.

Spiller Pena, Eduardo. Pajens da casa imperial: jurisconsultos, escravidão e a Lei de 1871. Campinas: Unicamp, 2001.

Thompson, Edward P. Costumes em comum: estudos sobre a cultura popular tradicional, trad. Rosária Eichenberg, 2aㅡ ed. São Paulo: Companhia das Letras, 1998.

Viana, Oliveira. Populações meridionais do Brasil. Brasília: Senado Federal, núm. 27, 2005.

Viotti da Costa, Emília. Da senzala à colônia. São Paulo: Brasiliense, 1989.

Wolmer, Antônio Carlos. História do direito no Brasil. 3 ed. rev. e amp., Rio de Janeiro: Forense, 2002.

\section{Capítulos de livros}

Nunes Ferreira, Gabriela. "Visconde do Uruguai: teoria e prática do Estado brasileiro", em Botelho, André e Moritz Schwarcz, Lilian (org.). Enigma chamado Brasil, São Paulo: Companhia das Letras, 2009.

\section{Artigos de revistas}

Arruda, Jose J. Andrade. "Experiência de classe e experimento historiográfico em E. P. Thompson”, em Revista do Programa de Estudos Pós-graduados de História, vol. XII, São Paulo, Pontifícia Universidade Católica, 1995.

Dolhnikoff, Miriam. "Elites regionais e a construção do estado nacional”, em Jancsó, István (org.). "Brasil: formação do Estado e da nação", em Estudos Históricos, núm. 50, São Paulo: Hucitec/Unijuí/Fapesp, 2003.

Ehlert Maia, João Marcelo. "Governadores de ruínas: os relatos de viagens de Couto Magalhães e Leite Moraes”, em Revista Estudos Históricos, núm. 40, Rio de Janeiro: Fundação Getúlio Vargas, julho/dezembro de 2007.

Eisenberg, Peter. "Ficando livre: as alforrias em Campinas no século XIX", em Revista Estudos Econômicos, vol. II, núm. 17, São Paulo: Universidade de São Paulo, maio/agosto de 1987.

\section{Publicações na Internet}

Melo, Rita C. Guimarães. "Vaqueiros e coronéis no Vale do Alto Tocantins (18891893): relato de um crime anunciado", em Associação Nacional dos Professores 
Universitários de História: conhecimento histórico e diálogo social XXVII, Natal, 2013, http://www.snh2013.anpuh.org/resources/anais/27/1376953581_ARQUIVO_ ArtigoAnpuh-16-08-2013.pdf.

Sá Netto, Rodrigo. "O Império brasileiro e a Secretaria de Estado dos Negócios da Justiça (1821-1891)”, em Memória da Administração Pública Brasileira, Rio de Janeiro: Arquivo Nacional, Cadernos Mapas núm. 2, 2011, http://www.portalan. arquivonacional.gov.br/media/2011\#.

\section{Teses}

Rodrigues, Neuma Brilhante. Nos caminhos do Império: a trajetória de Raimundo José da Cunha Mattos, (tese doutorado), Brasília: Universidade de Brasília, Instituto de Ciências Humanas, Departamento de História, 2007. 